Article

\title{
Sustainable Feasibility of the Environmental-Friendly Policies on Agriculture and Its Related Sectors in India
}

\author{
Jahira Debbarma ${ }^{1, *}$, Hyoungsuk Lee ${ }^{2}\left(\mathbb{D}\right.$ and Yongrok Choi ${ }^{1, *}$ (i) \\ 1 Program in Industrial Security Governance, Inha University, 100 Inha-ro, Incheon 22212, Korea \\ 2 Business School, Shandong University, Weihai 264209, China; zard2303@naver.com \\ * Correspondence: jahira@inha.edu (J.D.); yrchoi@inha.ac.kr (Y.C.)
}

Citation: Debbarma, J.; Lee, H.; Choi, Y. Sustainable Feasibility of the Environmental-Friendly Policies on Agriculture and Its Related Sectors in India. Sustainability 2021, 13, 6680 https://doi.org/10.3390/su13126680

Academic Editor: Dalia Štreimikienè

Received: 24 May 2021

Accepted: 9 June 2021

Published: 11 June 2021

Publisher's Note: MDPI stays neutral with regard to jurisdictional claims in published maps and institutional affiliations.

Copyright: (c) 2021 by the authors. Licensee MDPI, Basel, Switzerland. This article is an open access article distributed under the terms and conditions of the Creative Commons Attribution (CC BY) license (https:// creativecommons.org/licenses/by/ $4.0 /)$.

\begin{abstract}
In terms of economic development and feeding the world's populations, the importance of the agricultural sector is well known. However, agriculture and its related sectors are also known for contributing more than one-quarter of the world's GHG emissions. To address this issue, we evaluate the performance of agriculture and its related firms in India from 2013 to 2019 with its environmental efficiency under the paradigm shift promoted by the National Agroforestry Policy in 2014. To evaluate the feasibility of this paradigm shift in agricultural policy, the non-radial slack-based measure (SBM) is utilized in the first stage, and Tobit regressions are used to assess the determinants of efficiency (or sources of inefficiency) measures at the second stage. The results from non-radial SBM show that Indian agricultural firms (foreign direct investment, private, and public) show huge potential with $32.2 \%$ on average to enhance their performance if they move toward the frontier of the production possibility curve. This suggests that Indian policymakers should regulate much stronger regulations for firms, especially for the use of agricultural inputs such as energy (fertilizers), with performance-oriented financial measures for sustainable agriculture. To determine the strategic variables for these firms to enhance their performance, Tobit regressions showed that fertilizers use $(-3.350 \%)$ appears to have the highest negative impact on environmental efficiency. On the other hand, credit access $(2.710 \%)$ has the highest positive impact on environmental efficiency, implying that policymakers should provide subsidies to firms in the form of soft loans (or credit access) for the purchase of high-quality fertilizers and to adopt energy-saving equipment/technology to minimize the use of chemical fertilizers in India.
\end{abstract}

Keywords: environmental efficiency; non-radial slack-based measure; Tobit regression; agriculture; India

\section{Introduction}

Agriculture is the main engine for economic development and feeding the world's population in many countries. According to the World Bank, $65 \%$ of working poor adults made their living from agriculture in 2016 [1]. In the Indian economy, agriculture contributes to about $20 \%$ of the national gross domestic product (GDP), while about $58 \%$ of the Indian population depends on agriculture for their livelihood, directly or indirectly $[2,3]$. Figure 1 shows the trend of India's GDP coupling with agriculture and its related sector value-added (ARS-VA) from 2000 to 2019 [4,5]. From Figure 1, it can be seen that there is a significant coupling relationship between GDP and ARS-VA in India. When there is an increase in the growth of Indian GDP, there is also an increase in the number of ARS-VAs, which indicates that the agriculture sector plays an important role in boosting Indian GDP. However, even though there is a direct relationship between India's GDP and ARS-VA, the agriculture sectors are also known as major emitters of greenhouse gases (GHGs) into the atmosphere after the energy sectors. Figure 2 shows GHG emissions by sector in India from 2000 until 2018 (in Million Ton) [6]. It shows that after the energy sectors, the agricultural sector is the second-largest emitter of GHGs in 2018, with 22.63\% (including Land-Use 
Change and Forestry), implying that the agricultural sector should also be a major target in the GHG emission abatement. India is also the third-largest emitter of GHGs after China and the United States, and thus, Indian agriculture is exposed to stresses resulting from climate change due to emissions from agriculture and its related sectors. The increasing use of agricultural inputs (such as large amounts of energy consumption in the form of electricity, machinery, diesel fuel, fertilizers, human labor, etc.) used in agricultural production is the main driver of increasing GHG emissions in developing countries like India. Hence, we can say that the agricultural sectors also play a major role in the degradation of the Indian environment.

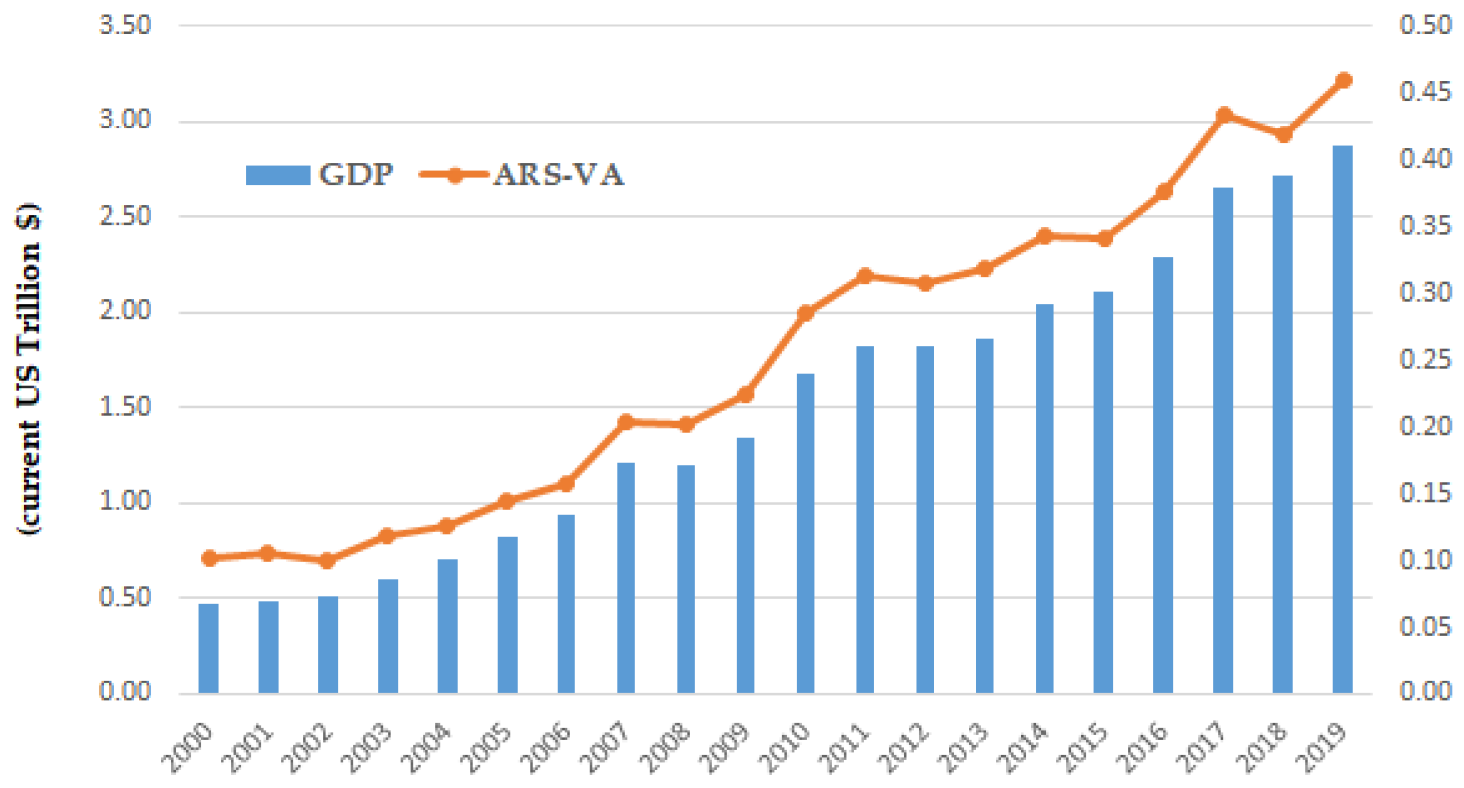

Figure 1. Trends of India's GDP and ARS-VA from 2000-2019.

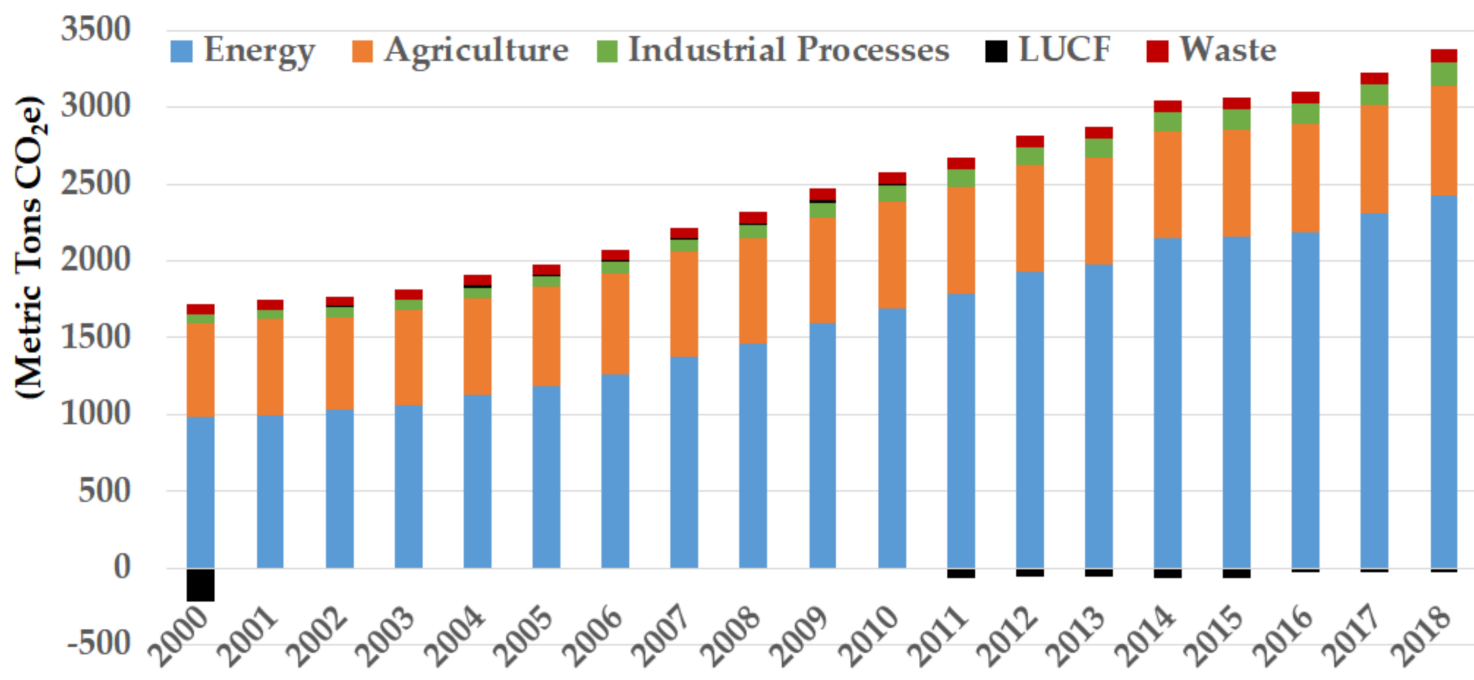

Figure 2. Sector-wise GHG emissions in India from 2000 to 2018.

Some studies on climate change have indicated that developing countries may be more disadvantaged than developed countries as the agricultural sector is under considerable pressure to identify the most effective climate change mitigation policies and 
measures [7,8]. India is not an exceptional case in this emerging new norm of environmental issues. Due to this global pressure, the agricultural sectors have been at the forefront of the UNFCCC negotiations since 2007, held at the Conference of Parties (COP 13) in Bali, Indonesia [9]. Mitigation in the agricultural sector and reducing greenhouse gas emissions while using limited energy resources are part of climate challenges to reduce environmental problems and increase agricultural sustainability. To fulfill the ambitious commitment to the international treaty of the UNFCCC, the creation of sustainable and climate-resilient agricultural systems has been put forward as part of India's plan to reduce the emission intensity of its GDP by 35\% by 2030, compared to 2005 levels. Meanwhile, India's National Agroforestry Policy aims to improve agricultural livelihoods to mitigate climate change by maximizing agricultural productivity. This policy was launched by the Indian government in February 2014, in which India became the first country in the world to adopt such a policy in agriculture sectors [10]. This policy also improves productivity and environmental sustainability by integrating crops, trees, and livestock in the same land plot. Nonetheless, this paradigm shift in the agriculture industry may not be strong enough for the industry/firms to improve its efforts for GHG abatement.

Based on the above discussion, this research aims to evaluate the environmental efficiency of agriculture and its related sectors in India to evaluate the feasibility of India's National Agroforestry Policy in 2014. Here, the environmental efficiency in this study is referring to the mitigation of the GHGs generated from agriculture and its related sectors in India. For this research objective, this paper seeks to address the following research questions based on the applied Indian policy mention in our study: Is India's agricultural sector performance sustainable in terms of environmental efficiency? Has the Indian agricultural sector's environmental efficiency changed in recent years based on the above policy applied? What are the main sources of inefficiency, and is there a way to improve the efficiency of the agricultural and its related sector in India? This study will not only help Indian farmers and policymakers but will also contribute to the interest of other developing countries to tackle GHG emissions from agriculture and its related sectors.

The structure of the article is as follows: Section 2 presents a review of the literature on the conceptual research model and variables of previous studies in the agricultural sector; Section 3 develops empirical models to assess the environmental efficiency of agriculture and its related sectors at the firm level in India; Section 4 gives descriptions about the data sources, then discusses the empirical result and its implications. Finally, Section 5 concludes the study by providing policy implications and suggestions regarding agricultural GHG emissions in India.

\section{Conceptual Research Model and Variables}

There is a wide variety of existing studies that assess the efficiency of agricultural sectors. Most of these studies use data envelopment analysis (DEA) applications when multiple inputs and outputs are considered simultaneously [11,12]. For example, Khoshroo et al. [11] studied the efficiency of turnip farms in Iran. The DEA model was applied with input variables like labor, machinery, seeds, fertilizer, and irrigation as well as desirable and undesirable output of turnip and emissions. On the other hand, Cecchini et al. [12] used livestock, labor, feed, an agricultural area, and capital as inputs variables and considered milk and $\mathrm{CO}_{2}$-eq as desirable and undesirable variables by adopting a slack-based measure of DEA (SBM-DEA) with undesirable output to quantify the marginal $\mathrm{CO}_{2}$ reduction costs of dairy cattle farms in Italy.

Since the traditional DEA model takes a radial approach, which might ignore slack variables and result in overestimation and low discriminating power, SBM-DEA has been widely used as an alternative to traditional DEA to capture the whole aspect of inefficiency in terms of input and output slacks in the efficiency measures. [12-14]. Therefore, in this study, we use the SBM-DEA with undesirable output to determine our study of efficiency evaluation. To calculate efficiency using the SBM-DEA model, we first need to identify the possible number of input and output variables. Considering the existing studies in Table 1, 
we have selected three input variables as employee, capital, and energy; one desirable output variable as sales turnover; and one undesirable output variable as GHG emissions.

Table 1. Research on the application of DEA and its integration with other models in the agricultural sector.

\begin{tabular}{|c|c|c|c|c|c|}
\hline \multirow{2}{*}{ Author(s) (Year) } & \multirow{2}{*}{$\begin{array}{c}\text { Field of } \\
\text { Application }\end{array}$} & \multicolumn{2}{|c|}{ First-Stage } & \multicolumn{2}{|c|}{ Second-Stage } \\
\hline & & Variables & Method & Variables & Method \\
\hline $\begin{array}{l}\text { Kuang et al. } \\
(2020)[15]\end{array}$ & $\begin{array}{l}\text { CLUE for } 31 \\
\text { provinces in China } \\
\text { from } 2000 \text { to } 2017 .\end{array}$ & $\begin{array}{l}\text { Land, labor, machinery, } \\
\text { fertilizers, pesticides, } \\
\text { plastic film, irrigation, } \\
\text { gross agricultural } \\
\text { production, output of } \\
\text { grain, and carbon } \\
\text { emissions. }\end{array}$ & SBM-DEA & $\begin{array}{l}\text { Natural condition, cultivated } \\
\text { land resource endowments, } \\
\text { agricultural production } \\
\text { condition, regional economic } \\
\text { development, and regional } \\
\text { science and technology } \\
\text { development. }\end{array}$ & Tobit model \\
\hline $\begin{array}{l}\text { Horvat et al. } \\
(2019)[16]\end{array}$ & $\begin{array}{l}\text { Technical efficiency } \\
\text { for } 25 \text { Serbian } \\
\text { districts. }\end{array}$ & $\begin{array}{l}\text { Utilized agricultural area, } \\
\text { livestock, labor, and } \\
\text { economic size. }\end{array}$ & Two-stage DEA & $\begin{array}{c}\text { Utilized agricultural area, } \\
\text { irrigated agricultural area, } \\
\text { education, years, and DEA } \\
\text { efficiency scores. }\end{array}$ & Tobit model \\
\hline Yan (2019) [17] & $\begin{array}{l}\text { Efficiency for } \\
\text { agricultural } \\
\text { enterprises }\end{array}$ & $\begin{array}{l}\text { Total assets, operating } \\
\text { costs, management costs, } \\
\text { and profit. }\end{array}$ & DEA & $\begin{array}{c}\text { Age, size, ROA, ownership } \\
\text { concentration, nature of } \\
\text { controlling shareholders, } \\
\text { and Crste. }\end{array}$ & Tobit model \\
\hline $\begin{array}{l}\text { Raheli et al. } \\
(2017)[18]\end{array}$ & $\begin{array}{l}\text { Efficiency for } \\
\text { tomato farming in } \\
\text { East Azerbaijan } \\
\text { province, Iran. }\end{array}$ & $\begin{array}{l}\text { Labor, machinery, } \\
\text { fertilizers, biocides, seed, } \\
\text { diesel fuel, water for } \\
\text { irrigation, and tomato. }\end{array}$ & DEA & $\begin{array}{c}\text { Age, area, education, and } \\
\text { manure. }\end{array}$ & $\begin{array}{l}\text { Fractional } \\
\text { regression }\end{array}$ \\
\hline $\begin{array}{l}\text { Vlontzos et al. } \\
\text { (2017) [19] }\end{array}$ & $\begin{array}{l}\text { Eco-(in)efficiency } \\
\text { index for EU } \\
\text { agricultural sector } \\
\text { from 1999-2012. }\end{array}$ & $\begin{array}{l}\text { Land, energy, chemicals } \\
\text { and fertilizers, fixed } \\
\text { capital, labor, output, and } \\
\text { GHG Emissions. }\end{array}$ & DEA & $\begin{array}{l}\text { Eco-efficiency, Energy, GHG } \\
\text { emissions }\end{array}$ & Regression Model \\
\hline $\begin{array}{l}\text { You et al. (2016) } \\
\text { [20] }\end{array}$ & $\begin{array}{l}\text { Eco-efficiency for } \\
31 \text { provinces in } \\
\text { China. }\end{array}$ & $\begin{array}{l}\text { Labor, machinery, } \\
\text { pesticide, diesel oil, } \\
\text { ammonia nitrogen } \\
\text { emission, total nitrogen } \\
\text { emission, and total } \\
\text { phosphorus emission. }\end{array}$ & $\begin{array}{l}\text { Input-oriented } \\
\text { DEA }\end{array}$ & $\begin{array}{l}\text { Education, farmland area, } \\
\text { income, wage, population, } \\
\text { population burden, fixed } \\
\text { assets, agriculture's position, } \\
\text { and industrialization level. }\end{array}$ & Tobit model \\
\hline Ray (2014) [21] & $\begin{array}{l}\text { Technical efficiency } \\
\text { for individual } \\
\text { states over the } \\
\text { years 1970-71 to } \\
\text { 2000-01. }\end{array}$ & $\begin{array}{l}\text { Land, fertilizers, irrigated } \\
\text { area, pump sets, tractors, } \\
\text { electricity, labor, rainfall, } \\
\text { food grains and nonfood } \\
\text { grains. }\end{array}$ & DEA & $\begin{array}{l}\text { Land, degree of openness, } \\
\text { education and research, } \\
\text { credit, crop diversification } \\
\text { index, literacy rate, gross } \\
\text { cropped area, irrigated area, } \\
\text { annual rainfall, input, } \\
\text { output, and } \\
\text { Pareto-Koopmans efficiency. }\end{array}$ & Regression Model \\
\hline $\begin{array}{c}\text { Hansson (2008) } \\
\text { [22] }\end{array}$ & $\begin{array}{l}\text { Efficiency for dairy } \\
\text { farms in Sweden. }\end{array}$ & $\begin{array}{l}\text { Fodder, labor, capital, } \\
\text { energy, seed, fertilizer, } \\
\text { milk, livestock, crops, } \\
\text { forage, and "other". }\end{array}$ & DEA & $\begin{array}{l}\text { Personal aspects, } \\
\text { management systems, farm } \\
\text { performance, efficiency } \\
\text { scores, aspects of the } \\
\text { management systems. }\end{array}$ & $\begin{array}{l}\text { Logistic and Tobit } \\
\text { regression }\end{array}$ \\
\hline
\end{tabular}

Based on our results of the SBM-DEA model, we obtain the efficiency score of agriculture and its related firms. However, to enhance the efficiency of these firms, we need to find out the determinants of efficiency measures; for this, we need a second stage of evaluation. In our model, we use the efficiency scores as the dependent variable, wherein dependent variables have some limits because efficiency never has the negative side of the value. Thus, due to this limited approach to dependent variables, the ordinary least square (OLS) model may give the estimate of a biased parameter [23], and thus most of the previous literature took the Tobit model as the role model [15-17]. The Tobit model also has the advantage of avoiding bias and inconsistencies when estimating unknown parameters with censored or limited variables, making it a more reliable choice to assess the determinants of environmental efficiency [14]. Kuang et al. [15] adopted the SBM model with undesirable outputs to analyze carbon emissions resulting from cultivated land-use efficiency in China. Along with the SBM model, they also employed a Tobit regression model to determine their study. In order to use this Tobit model, we need to 
select a second stage of the variables; similarly, different authors selected several variables for the DEA model and the Tobit regression, separately, for the evaluation of efficiency and to measure the determinants of efficiency measures in agricultural sectors at the same time [15-17,19,21]. Combining with the existing studies (Table 1), we believe that land [15], livestock [12], fertilizer [11], agricultural cultivation [15], urbanization rate [15], average rainfall [24], economics openness-export [25], and credit access [26] will have an influence on India's agriculture and its related sectors. Therefore, we use these eight explanatory variables for the Tobit model.

Some authors have already analyzed the efficiency of agricultural sectors at the firm level in their host country $[17,18,21]$. However, to the best of our knowledge, there is limited study on the environmental efficiency of agriculture and its related sectors at the firm level in India as firms can represent a main source of GHGs globally. Therefore, to fill the research gap, we assess agriculture and its related sector's environmental efficiency in India, based on firm-level data from 2013-2019.

\section{Material and Methods}

\subsection{SBM-DEA Model with Undesirable Outputs}

To estimate the environmental efficiency, there were many advantages to using DEA techniques, such as using DEA with undesirable output [16]. There are two types of DEA models, which can be categorized as radial and non-radial models. The SBM-DEA method of the non-radial and non-oriented approach is widely adopted, in which slacks of input and output are used to generate an efficiency estimate directly. The radial approach's inputs and outputs may lack information regarding the inactive (or neglected) efficiency of the inputs or outputs involved in the production process adjusted to the efficiency goal in the same proportion [27]. On the other hand, to classify and compare decision-making units (DMUs), the non-radial efficiency approach uses the slack variable, which results in a stronger discriminatory power and an unbiased estimate. As our study focuses on the precise and discriminating assessment of environmental performance at the firm level of agriculture and its related sectors, we use the SBM-DEA with an undesirable output for the empirical study $[12,13,15]$.

Let us assume that we have $\mathrm{n}$ decision-making units (DMUs), and each DMU consumed $\mathrm{m}$ inputs, which produced $\mathrm{g}_{1}$ desirable (good) output and $\mathrm{b}_{2}$ undesirable (bad) output. For $\mathrm{DMU}_{\mathrm{i}}$, the vectors of three factors can be defined as $X \in R^{\mathrm{m}}, \mathrm{Y}^{\mathrm{g}} \in \mathrm{R}^{\mathrm{g}}{ }_{1}$, and $Y^{\mathrm{b}}$ $\in R^{b_{2}}$, respectively. Then, the matrices $X, Y^{g}$, and $Y^{b}$ are specified as follows [13]: $X=\left[x_{1}\right.$, $\left.\mathrm{x}_{2}, \ldots, \mathrm{x}_{\mathrm{n}}\right] \in \mathrm{R}^{\mathrm{m} \times \mathrm{n}}, \mathrm{Y}^{\mathrm{g}}=\mathrm{y}_{1}^{\mathrm{g}}, \mathrm{y}_{2}^{\mathrm{g}}, \ldots, \mathrm{y}_{\mathrm{n}}^{\mathrm{g}}, \in \mathrm{R}^{\mathrm{g}} \mathrm{x}^{\times \mathrm{n}}$, and $\mathrm{Y}^{\mathrm{b}}=\mathrm{y}_{1}^{\mathrm{b}}, \mathrm{y}_{2}^{\mathrm{b}}, \ldots, \mathrm{y}_{\mathrm{n}^{\prime}}^{\mathrm{b}} \in \mathrm{R}^{\mathrm{b}_{2} \times \mathrm{n}}$, where $\mathrm{X}, \mathrm{Y}^{\mathrm{g}}$, and $\mathrm{Y}^{\mathrm{b}}>0$. Therefore, the SBM-DEA production technology under the constant returns to scale (CRS) of the production possibility set $(\mathrm{P})$ can be described in Equation (1) as follows [23]:

$$
\left.P=\left\{\left(X, Y^{g}, Y^{b}\right)\right\} \mid x \geq X \lambda, y^{g} \leq Y^{g} \lambda, y^{b} \geq Y^{b} \lambda, \lambda \geq 0\right\}
$$

Now, the SBM-DEA model with undesirable outputs can be described in Equation (2) as follows [28];

$$
\begin{gathered}
\mathrm{p}^{*}=\min \frac{1-\frac{1}{\mathrm{~m}} \sum_{\mathrm{i}=1}^{\mathrm{m}} \frac{\mathrm{s}_{\overline{\mathrm{i}}}}{\mathrm{x}_{\mathrm{i} 0}}}{1+\frac{1}{\mathrm{~g}_{1+} \mathrm{b}_{2}}\left(\sum_{\mathrm{r}=1}^{\mathrm{g}_{1}} \frac{\mathrm{s}_{\mathrm{r}}^{\mathrm{g}}}{\mathrm{y}_{\mathrm{r} 0}^{\mathrm{g}}}+\sum_{\mathrm{r}=1}^{\mathrm{b}_{2}} \frac{\mathrm{s}_{\mathrm{r}}^{\mathrm{b}}}{\mathrm{y}_{\mathrm{r} 0}^{\mathrm{b}}}\right)} \\
\text { s.t. }\left\{\begin{array}{c}
\mathrm{x}_{0}=X \lambda+\mathrm{s}^{-} ; \mathrm{y}_{0}^{\mathrm{g}}=\mathrm{Y}^{\mathrm{g}} \lambda-\mathrm{s}^{\mathrm{g}} ; \mathrm{y}_{0}^{\mathrm{b}}=\mathrm{Y}^{\mathrm{b}} \lambda+\mathrm{s}^{\mathrm{b}} \\
\mathrm{s}^{-} \geq 0, \mathrm{~s}^{\mathrm{g}} \geq 0, \mathrm{~s}^{\mathrm{b}} \geq 0, \lambda \geq 0
\end{array}\right\}
\end{gathered}
$$

$\lambda=$ the non-negative weight vector,

$\mathrm{s}^{-}$and $\mathrm{s}^{\mathrm{b}}=$ the overuse of inputs and undesirable outputs,

$\mathrm{s}^{\mathrm{g}}=$ the shortage of desirable outputs,

$0=$ the estimated DMU in the current model, respectively. 
If and only if $\rho^{*}=1$, then the DMU (firm) is considered to be efficient when all the slack variables are zero $\left(s^{-*}=s^{g *}=s^{b *}=0\right)$, even if there are undesirable outputs, and vice-versa for $\rho^{*}<1$. However, if firms are to become environmentally efficient, that is, to mitigate the GHGs generated from agriculture and its related sectors in India at the firm level, they must eliminate excess inputs and undesirable output while increasing and adjusting the deficit of desirable output. Here, inputs refer to the firm's employees, capital, and energy consumption; undesirable output related to GHG emissions generated by the firm; and the desirable output relating to the firm's sales turnover.

\subsection{Tobit Regression Model}

After we obtained the environmental efficiency of sample firms based on SBM-DEA, we used the regression model to analyze the determinants of environmental efficiency of sample firms as a second stage. As the residuals' expected value is necessarily zero in the OLS hypothesis, it may yield inconsistent or biased estimates when applying OLS on censored or truncated data [29]. Especially since the value of efficiency measures is between 0 and 1 in the SBM-DEA model with undesirable output, the traditional OLS estimation is not favorable for testing the determinants of environmental efficiency [15]. Therefore, the Tobit model is more popular for solving this methodological problem at the second stage with the efficiencies based on the DEA approach [15-17,19,21]. In a two-stage analysis procedure, the Tobit model is generally applied in efficiency literature [30-33]. Therefore, based on the Tobit regression approach, we can define the econometric model in Equation (3) as [26]:

$$
Y_{n p}=\left\{\begin{array}{c}
Y_{n p}=\beta^{T} x_{n p}+\epsilon_{n p} \beta^{T} x_{n p}+\epsilon_{n p} \\
0 \text { otherwise }
\end{array}\right\}
$$

$\mathrm{Y}_{\mathrm{np}}=$ the explained variable,

$\mathrm{x}_{\mathrm{np}}=$ the explanatory variable,

$\beta^{\mathrm{T}}=$ the vector of the regression coefficient of the explanatory variable,

$\epsilon_{\mathrm{np}}=$ the stochastic error assumed to follow the distribution of $\mathrm{N}\left(0, \sigma^{2}\right)$, respectively.

To assess the factors influencing inefficiency in agriculture and its related sectors, the Tobit model can be defined in Equation (4) as [29]:

$$
Y_{n p}=\beta_{0}+\beta_{1} Z^{1}{ }_{n p}+\beta_{2} Z^{2}{ }_{n p}+\beta_{3} Z_{n p}^{3} \ldots \beta_{x} Z^{X}{ }_{n p}+\epsilon_{n p}
$$

$\mathrm{Y}=$ the efficiency measure (or environmental efficiency of sample firms),

$\mathrm{np}=$ the $\mathrm{n}^{\text {th }}$ firms of sample study and the year or period of study,

$\beta_{\mathrm{x}}=$ the coefficient,

$\mathrm{Z}^{\mathrm{X}}{ }_{\mathrm{np}}=$ the explanatory variable,

$\epsilon_{\mathrm{np}}=$ the stochastic error, respectively.

\section{Data Collection and Empirical Results}

As this study aims to analyze the firms' environmental efficiency of agriculture and its related sectors in India, we collected data (56 firms) from 2013 to 2019. The sector in this study includes the following sub-sectors: dairy products, consumer goods and products, agri-food products, food and beverages, food production, fertilizers, agriculture, sugar, agrochemicals, agro-industry, farming, fishery, tea and coffee, and poultry and livestock.

\subsection{Input and Output Variables}

As mentioned in Section 2, we choose the three basic input variables; capital, employee, and energy consumption. As for outputs, sales turnover (desirable output) and GHG emissions (undesirable output) were considered. We extracted all the data from each firm's annual report provided on each firm's webpage. Regarding the capital input, we took into account the data on the firm's fixed assets published each year by the firm in their annual 
report, from 2013-2019. Likewise, for the employees' input, we choose the employees per head of each firm provided by the firm every year. Usually, in agriculture and its related sectors, researchers consider different types of desirable output, such as net value-added, agricultural production or agricultural output, profitability, etc. However, our research sample is based on firm-level data, so we use the firms' sales turnover, which is equivalent to the other desirable outcome. For sales turnover output, we have considered the revenue generated from the operations by the firms each year from 2013 to 2019. On the other hand, we collected the energy input and GHG emission output values using the macro level of agriculture and its related firms' data of power and fuel consumption rate provided by the firm in each year [34]. In case a firm did not provide the direct amount of energy it consumed and the direct amount of $\mathrm{CO}_{2}$ equivalent of GHGs it produced during the year, we then convert the power and fuel consumption rate into total energy consumption and $\mathrm{CO}_{2}$ equivalent of GHG emissions. All the descriptive statistics of input and output variables are shown in Table 2.

Table 2. Descriptive statistics of input and output variables from 2013-2019.

\begin{tabular}{|c|c|c|c|c|c|c|}
\hline Firm & Variable (Unit) & Input/Output & Mean & Std. Deviation & Maximum & Minimum \\
\hline \multirow{5}{*}{ FDI } & Employee (Per person) & Input & 2433.381 & 2133.565 & 7649.000 & 252.000 \\
\hline & Capital (Million rupees) & Input & 8655.340 & $10,616.070$ & $47,160.000$ & 524.340 \\
\hline & Energy $(\mathrm{Gj})$ & Input & $342,959.633$ & $408,573.477$ & $1,522,000.000$ & 6368.390 \\
\hline & Sales turnover (Million rupees) & Desirable output & $57,201.725$ & $77,509.104$ & $388,880.000$ & 4593.300 \\
\hline & GHG emissions (Tons) & Undesirable output & $12,775.394$ & $14,428.415$ & $54,417.650$ & 227.670 \\
\hline \multirow{5}{*}{ Private } & Employee (Per person) & Input & 1557.024 & 1551.181 & 5173.000 & 177.000 \\
\hline & Capital (Million rupees) & Input & 2591.291 & 3645.471 & $16,409.580$ & 150.000 \\
\hline & Energy $(\mathrm{Gj})$ & Input & $10,355.371$ & $11,937.045$ & $47,663.470$ & 1881.650 \\
\hline & Sales turnover (Million rupees) & Desirable output & $94,946.336$ & $152,120.579$ & $741,000.000$ & 2270.280 \\
\hline & GHG emissions (Tons) & Undesirable output & 4323.290 & 8289.132 & $47,312.370$ & 81.160 \\
\hline \multirow{5}{*}{ Public } & Employee (Per person) & Input & 1066.837 & 1100.962 & 5077.000 & 6.000 \\
\hline & Capital (Million rupees) & Input & $129,638.839$ & $764,029.248$ & $5,652,745.300$ & 12.630 \\
\hline & Energy $(\mathrm{Gj})$ & Input & $2,420,438.986$ & $12,638,523.524$ & $83,526,299.200$ & 337.800 \\
\hline & Sales turnover (Million rupees) & Desirable output & $498,961.030$ & $1,607,358.846$ & $10,305,640.400$ & 2306.730 \\
\hline & GHG emissions (Tons) & Undesirable output & $35,916.885$ & $119,537.804$ & $729,131.140$ & 116.140 \\
\hline
\end{tabular}

In India, there are three types of firms in the agricultural sectors: private, public, and foreign direct investment (FDI) firms (Table 2). Each group of firms may respond differently to the regulatory policies of the government on the agriculture sectors, and thus may result in more precise implications and customized suggestions in our research. It is, therefore, important to analyze these three types of firms and assess their performance in terms of sustainable agriculture [35]. According to the reports [36], to launch India's GHG Program, representatives from some firms, including Bayer Group from FDI group and Tata Chemicals from a private local group and its related sectors, have joined the environmentalist and government leaders to foster sustainable profitability competitive firms. On this basis, we compare the performance between FDI, private firms, and public firms to assess these firms' environmental efficiency and see if there is a difference between these groups in the patterns of environmental efficiency.

Based on Table 3, the correlation between the firms' input and output variables is almost significantly positive. This means that the output values will increase or decrease depending on the input usage during the production process. Both employee and capital are positively correlated with sales turnover because they are the representative variables to explain production. On the other hand, there is a significant relationship between capital and energy consumption, which indicates that when the firm purchases and upgrades energy-saving equipment, it will also affect its energy consumption in question [37]. While the GHG emissions show a positive relationship for energy input and sales turnover output, energy and GHG emissions show a very significant relationship [34]. Therefore, we can conclude that this formulation is appropriate when analyzing the data from an environmental point of view. 
Table 3. Correlation Matrix of input and output variables.

\begin{tabular}{cccccc}
\hline Variables & Employee & Capital & Energy & $\begin{array}{c}\text { Sales } \\
\text { Turnover }\end{array}$ & $\begin{array}{c}\text { GHG } \\
\text { Emissions }\end{array}$ \\
\hline Employee & 1.000 & & & & \\
Capital & 0.297 & 1.000 & & & \\
Energy & 0.324 & 0.964 & 1.000 & & \\
Sales turnover & 0.300 & 0.368 & 0.362 & 1.000 & \\
GHG emission & 0.412 & 0.367 & 0.915 & 0.874 & 1.000 \\
\hline
\end{tabular}

Environmental Efficiency of Indian Agriculture and Its Related Firms

Based on Equations (1) and (2), Table 4 illustrates the environmental efficiency of 56 Indian agricultures and its related firms for seven consecutive years (2013-2019). As discussed in Section 4.1, we classified sample firms into three types-FDI, private, and public firms in India - and compare their environmental efficiency. Due to privacy concerns, we used the firm's identification (id) name as equivalent to the firm's name. The overall environmental efficiency scores range from 0.156 to 1 , and the average of FDI, the private firms, and the public firms is approximately $0.609,0.569$, and 0.675 , respectively. This implies that $39.1 \%$ of the FDI firms, $43.1 \%$ of the private firms, and $32.5 \%$ of the public firms can be obtained if they are located on the frontier. Among 56 firms, ALIL, a public firm, is the only firm showing environmental efficiency score of 1, indicating that ALIL adjusts to the environmental regime very well. This result stems from that ALIL has already reviewed their performance in implementing the policy, annually and periodically, and updated it as needed to be an integral part of the Indian environmental sustainability vision. As expected, public firms make more efforts to adopt the paradigm shift of the policies. While the highest efficiency scores among FDI and private firms in 2019 are BI and BRL, respectively, compared to ALIL, these firms still need an efficiency increase of $14.7 \%$ and $15.4 \%$ to reach their target. The reason could be that FDI firms are insensitive and not proactive in implementing local regulatory policies in the host country. Meanwhile, Indian firms (especially private firms) are more interested in hassle-free short-term gains other than a long-term vision like the national agroforestry policy [38]. As a result, firms opt for short-period, benefit-related policies in India, which could lead to unsustainable policy implementation and lead to environmental degradation among FDI and private firms.

Table 4. Environmental efficiency of agriculture and its related firms (2013-2019).

\begin{tabular}{cccccccccc}
\hline Firms Id & $\begin{array}{c}\text { Firm } \\
\text { Type }\end{array}$ & $\mathbf{2 0 1 3}$ & $\mathbf{2 0 1 4}$ & $\mathbf{2 0 1 5}$ & $\mathbf{2 0 1 6}$ & $\mathbf{2 0 1 7}$ & $\mathbf{2 0 1 8}$ & $\mathbf{2 0 1 9}$ & Average \\
\hline AFL & FDI & 0.457 & 0.594 & 0.697 & 0.781 & 0.811 & 0.873 & 0.865 \\
BIL & FDI & 0.340 & 0.377 & 0.376 & 0.481 & 0.621 & 0.743 & 0.878 & 0.725 \\
BI & FDI & 0.776 & 0.675 & 0.630 & 0.849 & 0.882 & 0.852 & 0.853 & 0.788 \\
BIL & FDI & 0.557 & 0.560 & 0.611 & 0.786 & 0.879 & 0.820 & 0.817 & 0.719 \\
CIL & FDI & 0.406 & 0.416 & 0.522 & 0.631 & 0.709 & 0.823 & 0.842 & 0.621 \\
DAL & FDI & 0.536 & 0.524 & 0.532 & 0.604 & 0.704 & 0.837 & 0.876 & 0.659 \\
ECCL & FDI & 0.319 & 0.455 & 0.445 & 0.506 & 0.708 & 0.836 & 0.850 & 0.588 \\
GSCHL & FDI & 0.436 & 0.478 & 0.498 & 0.599 & 0.699 & 0.702 & 0.843 & 0.608 \\
GAL & FDI & 0.314 & 0.406 & 0.418 & 0.594 & 0.628 & 0.815 & 0.825 & 0.571 \\
HUL & FDI & 0.417 & 0.495 & 0.401 & 0.681 & 0.750 & 0.939 & 0.851 & 0.648 \\
IIL & FDI & 0.251 & 0.279 & 0.384 & 0.488 & 0.506 & 0.701 & 0.804 & 0.488 \\
MIL & FDI & 0.325 & 0.478 & 0.473 & 0.560 & 0.677 & 0.869 & 0.863 \\
NIL & FDI & 0.235 & 0.252 & 0.337 & 0.460 & 0.686 & 0.613 & 0.737 & 0.606 \\
RIL & FDI & 0.270 & 0.289 & 0.393 & 0.461 & 0.503 & 0.598 & 0.712 & 0.474 \\
TP\&GC & FDI & 0.410 & 0.494 & 0.515 & 0.628 & 0.737 & 0.776 & 0.843 & 0.629 \\
AFF & Private & 0.293 & 0.468 & 0.491 & 0.411 & 0.687 & 0.870 & 0.854 & 0.582 \\
AAL & Private & 0.298 & 0.340 & 0.420 & 0.489 & 0.766 & 0.815 & 0.900 & 0.575 \\
\hline
\end{tabular}


Table 4. Cont.

\begin{tabular}{|c|c|c|c|c|c|c|c|c|c|}
\hline Firms Id & $\begin{array}{l}\text { Firm } \\
\text { Type }\end{array}$ & 2013 & 2014 & 2015 & 2016 & 2017 & 2018 & 2019 & Average \\
\hline BRL & Private & 0.427 & 0.374 & 0.452 & 0.457 & 0.707 & 0.838 & 0.846 & 0.586 \\
\hline HAPL & Private & 0.380 & 0.355 & 0.387 & 0.405 & 0.676 & 0.844 & 0.847 & 0.556 \\
\hline KSCL & Private & 0.322 & 0.376 & 0.439 & 0.495 & 0.657 & 0.875 & 0.852 & 0.574 \\
\hline ML & Private & 0.283 & 0.311 & 0.388 & 0.390 & 0.684 & 0.862 & 0.871 & 0.541 \\
\hline ALIL & Public & 1.000 & 1.000 & 1.000 & 1.000 & 1.000 & 1.000 & 1.000 & 1.000 \\
\hline CCL & Public & 0.410 & 0.449 & 0.608 & 0.707 & 0.856 & 0.869 & 0.945 & 0.692 \\
\hline DSML & Public & 0.276 & 0.380 & 0.757 & 0.806 & 0.806 & 0.820 & 0.922 & 0.681 \\
\hline DDL & Public & 0.376 & 0.289 & 0.566 & 0.619 & 0.707 & 0.794 & 0.850 & 0.600 \\
\hline DSIL & Public & 0.256 & 0.248 & 0.464 & 0.630 & 0.693 & 0.728 & 0.786 & 0.544 \\
\hline FCL & Public & 0.368 & 0.283 & 0.475 & 0.611 & 0.670 & 0.733 & 0.880 & 0.574 \\
\hline GOL & Public & 0.530 & 0.799 & 0.880 & 0.853 & 0.857 & 1.000 & 0.952 & 0.839 \\
\hline HFL & Public & 0.327 & 0.317 & 0.550 & 0.657 & 0.774 & 0.857 & 0.724 & 0.601 \\
\hline ISL & Public & 0.200 & 0.278 & 0.444 & 0.596 & 0.662 & 0.674 & 0.750 & 0.515 \\
\hline KSML & Public & 0.325 & 0.392 & 0.642 & 0.657 & 0.787 & 0.753 & 0.837 & 0.628 \\
\hline KI & Public & 0.755 & 0.823 & 0.902 & 0.928 & 0.928 & 1.000 & 1.000 & 0.905 \\
\hline KL & Public & 1.000 & 1.000 & 0.973 & 0.905 & 0.893 & 0.875 & 0.808 & 0.922 \\
\hline LCCL & Public & 0.312 & 0.468 & 0.505 & 0.736 & 0.850 & 0.827 & 0.815 & 0.645 \\
\hline MFL & Public & 1.000 & 1.000 & 0.632 & 0.763 & 0.803 & 0.738 & 0.750 & 0.812 \\
\hline MC\&FL & Public & 0.625 & 0.324 & 0.397 & 0.516 & 0.691 & 0.602 & 0.725 & 0.554 \\
\hline NIL & Public & 0.246 & 0.245 & 0.273 & 0.570 & 0.714 & 0.709 & 0.711 & 0.495 \\
\hline NS & Public & 0.307 & 0.386 & 0.550 & 0.764 & 0.806 & 0.816 & 0.808 & 0.634 \\
\hline OFL & Public & 0.935 & 1.000 & 0.860 & 0.966 & 0.926 & 0.835 & 0.895 & 0.917 \\
\hline PMFL & Public & 0.259 & 0.270 & 0.419 & 0.517 & 0.724 & 0.819 & 0.839 & 0.550 \\
\hline PSL & Public & 0.156 & 0.265 & 0.347 & 0.481 & 0.673 & 0.719 & 0.824 & 0.495 \\
\hline RPL & Public & 0.420 & 0.481 & 0.425 & 0.722 & 0.820 & 0.822 & 0.883 & 0.653 \\
\hline HGAIL & Public & 0.336 & 0.317 & 0.454 & 0.653 & 0.721 & 0.803 & 0.870 & 0.593 \\
\hline SFL & Public & 0.665 & 0.675 & 0.790 & 0.872 & 0.863 & 0.855 & 0.851 & 0.796 \\
\hline SSLEL & Public & 0.251 & 0.547 & 0.652 & 0.873 & 0.889 & 0.864 & 0.825 & 0.700 \\
\hline SEPEL & Public & 0.312 & 0.257 & 0.395 & 0.590 & 0.766 & 0.713 & 0.805 & 0.548 \\
\hline SPICL & Public & 0.236 & 0.301 & 0.486 & 0.668 & 0.837 & 0.881 & 0.840 & 0.607 \\
\hline TCL & Public & 0.762 & 0.363 & 0.449 & 0.653 & 0.808 & 0.830 & 0.816 & 0.669 \\
\hline TCPL & Public & 0.525 & 0.648 & 0.514 & 0.723 & 0.889 & 0.889 & 0.888 & 0.725 \\
\hline TF\&CTL & Public & 0.414 & 0.798 & 0.430 & 0.651 & 0.797 & 0.768 & 0.814 & 0.667 \\
\hline TUSWL & Public & 0.221 & 0.520 & 0.462 & 0.511 & 0.754 & 0.892 & 0.823 & 0.598 \\
\hline TWL & Public & 0.516 & 0.715 & 0.618 & 0.715 & 0.819 & 0.826 & 0.825 & 0.719 \\
\hline ZAL & Public & 0.227 & 0.599 & 0.456 & 0.544 & 0.788 & 0.878 & 0.832 & 0.618 \\
\hline ZACL & Public & 0.551 & 0.803 & 0.684 & 0.827 & 0.840 & 0.830 & 0.831 & 0.767 \\
\hline ZGL & Public & 0.598 & 0.814 & 0.578 & 0.808 & 0.866 & 0.864 & 0.943 & 0.782 \\
\hline $\mathrm{RC} \& \mathrm{~F}$ & Public & 0.220 & 0.530 & 0.400 & 0.480 & 0.800 & 0.810 & 0.905 & 0.592 \\
\hline FDI Firm & & 0.403 & 0.451 & 0.482 & 0.607 & 0.700 & 0.786 & 0.831 & 0.609 \\
\hline $\begin{array}{l}\text { Private } \\
\text { Firm }\end{array}$ & & 0.334 & 0.371 & 0.430 & 0.441 & 0.696 & 0.851 & 0.862 & 0.569 \\
\hline $\begin{array}{l}\text { Public } \\
\text { Firm }\end{array}$ & & 0.455 & 0.531 & 0.572 & 0.702 & 0.802 & 0.820 & 0.845 & 0.675 \\
\hline Average & & 0.397 & 0.451 & 0.495 & 0.583 & 0.733 & 0.819 & 0.846 & 0.618 \\
\hline
\end{tabular}

To find out the effect of a paradigm shift on the regulatory policies, we need to analyze the environmental efficiency trend of each group. Figure 3 shows the trend of environmental efficiency of Indian agriculture and its related firms (FDI, private, and public) during 2013-2019. The three groups started from the lowest efficiency value in 2013 and achieved the highest average efficiency in 2019. This steady increasing trend strongly supports the Porter hypothesis since regulation leads to increased performance throughout all the FDI, private, and public firms. With regard to respective group performance, it is notable that the private firms group shows very rapidly increasing environmental efficiency. This group showed lower than FDI and public in 2013; however, it finally surpassed them 
after 2018. The reason could be due to the demonetization of the banknote in India in 2016. Banknotes account for $86 \%$ of the country's circulating cash, but their effects were only felt for its fiscal year in 2016. Transactions in the Indian agricultural sector (especially private firms) are heavily dependent on liquidity, which, in turn, could have impacted the private firm group's performance in terms of environmental efficiency in 2016 [38,39]. Since the private firms are the most sensitive to the financial measures, this result suggests that a more customized financial support for environmentally friendly agricultural firms will result in stronger performance on GHG emission abatement. Furthermore, in terms of GHG measurement guidelines and a national benchmarking system, Indian firms still face a lack of uniformity and lack of managerial innovation, although they recognize the benefits of sustainable firms' practices, implying financial incentives by the government as one of the best market-oriented measures [36].

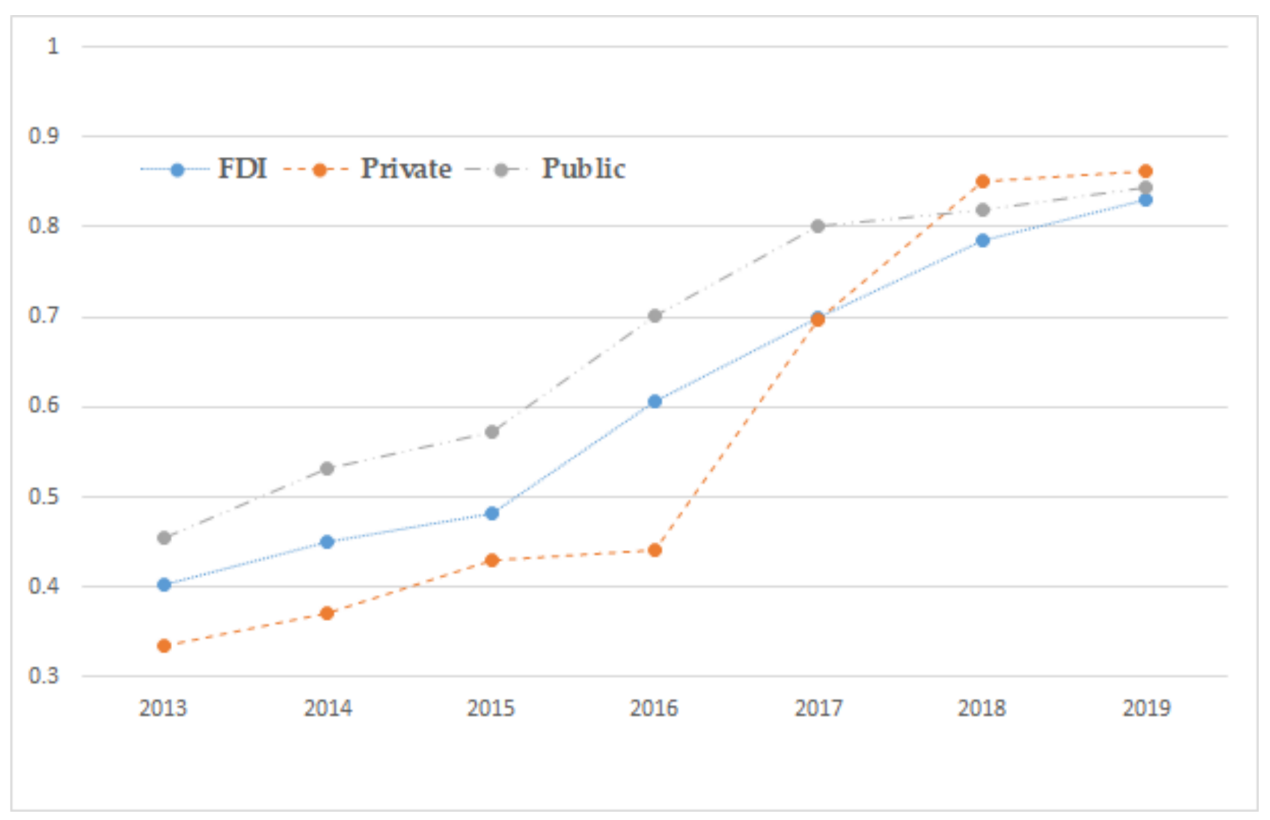

Figure 3. Trends of agriculture and its related firm's environmental efficiency.

\subsection{Descriptive Statistics for Factors Affecting Inefficiency in Indian Agricultural Firms}

Based on the result of environmental efficiency, we may find out the answer to the research question: What are the main sources of inefficiency, and is there a way to improve the efficiency of the agricultural and its related sector in India? To address this issue, we conducted Tobit regression for the determinants of efficiency (or sources of inefficiency) measures as the second stage of this study. As discussed in Section 2, we selected the eight explanatory variables: land, livestock, fertilizers, various agriculture cultivation, urbanization rate, climate change-average rainfall, economics openness-export, and credit, as determinants of efficiency (or source of inefficiency) measures in agriculture and its related sectors. Due to the lack of firm data, we could not select all 56 firms; instead, we chose 30 out of 56 firms to deploy Tobit regression in the second stage of our study. We have collected all the explanatory variables from the annual report of 30 firms from agriculture and its related sectors for 2019. For urbanization rate data, we refer to the data from Census of India, Govt. of India and Reserve Bank of India, Handbook of Statistics on Indian States [40,41]. We considered the state-level Population in Urban Area as the urbanization rate data as there was insufficient data from the firms. Then, we segmented our selected firms into state-level and extracted the data, as each firm is located in different states. Likewise, due to the limited data, we were unable to extract the average rainfall data from the firm; instead, we collected the data from the Indian Meteorological department, Ministry of Earth Science, New Delhi, at state level [42]. For the dependent data, we chose 
the efficiency scores from the first stage. Descriptive statistics for these determining factors are shown in Table 5.

Table 5. Descriptive statistics for determining factors explaining inefficiency in Agricultural firms.

\begin{tabular}{ccccc}
\hline Explanatory Variables (Unit) & Mean & Std. Deviation & Maximum & Minimum \\
\hline Land (Million rupees) & 0.75 & 0.70 & 4.90 & 0.20 \\
Livestock (Tons) & $11,052.00$ & 6502.46 & $30,000.00$ & 0.00 \\
Fertilizers (Kg. Per Hectare) & 100.83 & 27.73 & 143.00 & 11.00 \\
Agricultural cultivation (Mil. hectares) & 22.13 & 6.96 & 32.23 & 3.24 \\
Urbanization rate (Percentage) & 30.00 & 8.746 & 40.620 & 6.800 \\
Average rainfall (Millimeter) & 1226.60 & 833.56 & 4321.00 & 108.00 \\
Economics openness- export (Million rupees) & 286.93 & 298.35 & 1029.19 & 1.63 \\
Credit access (Million rupees) & 5171.53 & 1522.62 & $11,621.76$ & 1000.84 \\
\hline
\end{tabular}

Results of Tobit Regression

For the determinants to enhance environmental efficiency, Table 6 shows the results of the Tobit model with the comparative results of the OLS to determine whether they have a significant difference with each other. Indeed, as shown in Table 6, the OLS estimates show a different pattern from those of Tobit estimates in terms of the significance level. As mentioned in Section 2, the Tobit model has the advantage of being used to avoid bias and inconsistencies when estimating unknown parameters, making a more appropriate choice for evaluating the determinants of environmental efficiency [43]. Besides this, the results of the OLS model contradict the Tobit model in many respects. In the Tobit model, the use of fertilizer has a strong negative effect on environmental efficiency, while OLS does not have any statistical significance regarding that at all, contradictorily against the fact that most agricultural firms heavily depend on fertilizers. Therefore, the OLS approach results in not only theoretical bias on the limited dependent variable of environmental efficiency but the practically unacceptable implications [44]. Therefore, we concluded that Tobit regression is a superior methodology in this study and offers more appropriate implications in theoretical as well as practical perspectives.

Table 6. Comparison of empirical results of Tobit and OLS models.

\begin{tabular}{|c|c|c|c|c|c|}
\hline \multicolumn{6}{|c|}{ Dependent Variable $=$ Efficiency Scores from the First Stage of the DEA Application } \\
\hline \multirow[b]{2}{*}{ Explanatory Variables } & \multirow[b]{2}{*}{ Unit } & \multicolumn{2}{|c|}{ OLS Model } & \multicolumn{2}{|c|}{ Tobit Model } \\
\hline & & Coefficient & t-Statistics & Coefficient & t-Statistics \\
\hline Land & Million rupees & 0.742 & $5.690 * * *$ & 0.765 & $3.130 * * *$ \\
\hline Livestock & Tons & -1.575 & $-2.830 * * *$ & -1.850 & -1.310 \\
\hline Fertilizer & Kg. Per Hectare & -2.836 & -0.595 & -3.350 & $-2.905^{* * *}$ \\
\hline Agricultural cultivation & Million hectares & -0.020 & $-5.450 * * *$ & -0.010 & $-5.030^{* * *}$ \\
\hline Urbanization rate & Percentage & -0.030 & $-1.740 *$ & -0.027 & -1.090 \\
\hline Average rainfall & Millimeter & 0.152 & $1.772 *$ & 0.051 & 1.122 \\
\hline Economics openness-export & Million rupees & 0.015 & $4.720 * * *$ & 0.013 & $2.160^{* *}$ \\
\hline Credit access & Million rupees & 2.579 & $2.560 * *$ & 2.710 & $2.150^{* *}$ \\
\hline Industry fixed effects & & \multicolumn{2}{|c|}{ Yes } & \multicolumn{2}{|c|}{ Yes } \\
\hline FDI/Private/Public fixed effects & & \multicolumn{2}{|c|}{ Yes } & \multicolumn{2}{|c|}{ Yes } \\
\hline Year fixed effects & & \multicolumn{2}{|c|}{ Yes } & \multicolumn{2}{|c|}{ Yes } \\
\hline Year of observation & & \multicolumn{2}{|c|}{2019} & \multicolumn{2}{|c|}{2019} \\
\hline
\end{tabular}

Note: ${ }^{* * *},{ }^{* *}$ and ${ }^{*}$ indicates the significance level of $1 \%, 5 \%$ and $10 \%$ respectively.

According to the Tobit regression result, among other variables, two variables (fertilizer and agricultural cultivation) show a negative influence on environmental efficiency, at the significance level of $99 \%$. Fertilizer use appears to have the highest negative impact on India's environmental efficiency. A 1\% increase in fertilizer use will reduce India's 
environmental efficiency by $3.350 \%$. Moreover, some experts have also argued that the overuse and imbalanced use of fertilizers in some parts of India has caused environmental degradation problems in India [45-47]. Our empirical result certainly supports this view of the fertilizer issues on the environment of India. In addition, Indian environmental efficiency is negatively affected by various rice cultivation every year. This means that if there is more agricultural cultivation in India, GHG emissions are likely to increase and affect environmental efficiency, leading to environmental degradation. However, apart from rice cultivation, the intensity of GHG emissions from other crops has remained reasonably low because these crops are grown in rainfed conditions in India. Furthermore, to reduce GHG emissions from rice fields, the government has proposed additional sustainable agriculture actions [47]. In contrast to two negative variables, land, economics openness-export, and credit access positively impact Indian environmental efficiency significantly. In addition, export has a positive impact on Indian environmental efficiency, which means that larger exports will not harm Indian environmental efficiency, as India is one of the major exporters of agriculture and its related sector. Finally, credit access appears to have positively impacted Indian environmental efficiency, which means that Indian firms need more sources of finance to improve the environmental efficiency of agriculture and its related sectors through advanced equipment or techniques. On the other hand, livestock, urbanization rate, and average rainfall did not show statistical significance on environmental efficiency.

\section{Conclusions}

This study analyzes the environmental efficiency of agriculture and its related firms in India for seven consecutive years (2013-2019). We used the SBM-DEA method in the first stage of our study to determine the environmental efficiency of sample firms. In the second stage of this study, we used the Tobit model to find out the determinants of efficiency (or sources of inefficiency).

Empirical results and implications are summarized as follows. First, the non-radial SBM-DEA approach showed huge potential with $32.3 \%$ on average for the Indian firms of FDI, private, and public groups to improve their performance if they move toward the production frontier. This indicates that Indian firms still have to improve the agricultural sector's performance to make it sustainable. Second, for the effect of a paradigm shift on the environment-friendly policies in recent years, our results showed an improvement in environmental efficiency in India at the firm level during the research period. Nonetheless, the trend shows a very smooth and marginal improvement trend among the agricultural firms regardless of different classification among the three groups, FDI, private, and public firms. This suggests that the regulation should be much stronger in terms of the use of agricultural inputs such as energy (fertilizers) in India, especially on the FDI firms with precisely performance-oriented customized financial measures, as agricultural sectors are the primary sectors in the Indian economy. Third, to find out the main sources of inefficiency and a way to improve the efficiency of the agricultural and its related sector in India, we deployed a Tobit regression model in the second stage of this study. We found that two variables, fertilizer and agricultural cultivation of rice, negatively impact India's environmental efficiency, suggesting that fertilizer use and cultivation of agriculture should be minimized to improve the efficiency of agriculture and its related sectors in India. Here, we suggest that the Indian government provide designated loans or grants to agricultural firms in the form of soft loans (or credit access) for the purchase of highquality fertilizers and to adopt energy-saving equipment/technology to minimize the use of chemical fertilizers. As shown in the Tobit regression result, the credit access shows the highest positive relationship to India's environmental efficiency and vice versa for fertilizer use.

This research shed light on the optimal path of the regulatory as well as the promotional policies for an environmentally friendly agriculture industry in developing countries. In most developing countries, the agriculture industry may be the largest or a major engine of economic development. Thus, more precise, appropriate policies to enhance 
green growth are feasible and sustainable, with a strong lead through the regulation and promotion policies in more performance-oriented ways.

Author Contributions: Conceptualization, Y.C. and J.D.; methodology and software, J.D.; validation, Y.C.; formal analysis, J.D.; investigation, J.D.; resources and data collection, J.D.; writing—original draft preparation, J.D.; writing — review and editing, Y.C. and H.L.; supervision, Y.C.; project administration, Y.C.; funding acquisition Y.C. All authors have read and agreed to the published version of the manuscript.

Funding: This research received no external funding.

Institutional Review Board Statement: Not applicable.

Informed Consent Statement: Not applicable.

Data Availability Statement: Not applicable.

Conflicts of Interest: The authors declare no conflict of interest.

\section{References}

1. Agriculture and Food. Available online: https://www.worldbank.org/en/topic/agriculture/overview (accessed on 22 December 2020).

2. Vetter, S.H.; Sapkota, T.B.; Hillier, J.; Stirling, C.M.; Macdiarmid, J.I.; Aleksandrowicz, L.; Smith, P. Greenhouse gas emissions from agricultural food production to supply Indian diets: Implications for climate change mitigation. Agric. Ecosyst. Environ. 2017, 237, 234-241. [CrossRef] [PubMed]

3. Agriculture in India: Information About Indian Agriculture \& Its Importance. Available online: https://www.ibef.org/industry/ agriculture-india.aspx (accessed on 14 May 2021).

4. GDP (Current US\$)—India. Available online: https:// data.worldbank.org/indicator/NY.GDP.MKTP.CD?locations=IN (accessed on 14 May 2021).

5. Agriculture, forestry, and Fishing, Value Added (Current US\$)—India. Available online: https://data.worldbank.org/indicator/ NV.AGR.TOTL.CD?locations=IN (accessed on 14 May 2021).

6. Historical GHG Emissions. Available online: https:/ / www.climatewatchdata.org/ghg-emissions?breakBy=sector\&end_year=20 18\&regions=IND\&start_year=1990 (accessed on 14 May 2021).

7. Mertz, O.; Halsnæs, K.; Olesen, J.E.; Rasmussen, K. Adaptation to climate change in developing countries. Environ. Manag. 2009, 43, 743-752. [CrossRef] [PubMed]

8. Mendelsohn, R. The impact of climate change on agriculture in developing countries. J. Nat. Resour. Policy Res. 2008, 1, 5-19. [CrossRef]

9. IPCC. Available online: https://report.ipcc.ch/sr15/pdf/sr15_spm_final.pdf (accessed on 14 May 2021).

10. Agricoop. Available online: https://agricoop.gov.in/sites/default/files/National_agroforestry_policy_2014.pdf (accessed on 17 May 2021).

11. Khoshroo, A.; Izadikhah, M.; Emrouznejad, A. Improving energy efficiency considering reduction of CO2 emission of turnip production: A novel data envelopment analysis model with undesirable output approach. J. Clean. Prod. 2018, 187, 605-615. [CrossRef]

12. Cecchini, L.; Venanzi, S.; Pierri, A.; Chiorri, M. Environmental efficiency analysis and estimation of CO2 abatement costs in dairy cattle farms in Umbria (Italy): A SBM-DEA model with undesirable output. J. Clean. Prod. 2018, 197, 895-907. [CrossRef]

13. Le, T.L.; Lee, P.P.; Peng, K.C.; Chung, R.H. Evaluation of total factor productivity and environmental efficiency of agriculture in nine East Asian countries. Agric. Econ. 2019, 65, 249-258.

14. Zhang, J.; Zeng, W.; Shi, H. Regional environmental efficiency in China: Analysis based on a regional slack-based measure with environmental undesirable outputs. Ecol. Indic. 2016, 71, 218-228. [CrossRef]

15. Kuang, B.; Lu, X.; Zhou, M.; Chen, D. Provincial cultivated land use efficiency in China: Empirical analysis based on the SBM-DEA model with carbon emissions considered. Technol. Forecast. Soc. Chang. 2020, 151, 119874. [CrossRef]

16. Horvat, A.M.; Radovanov, B.; Popescu, G.H.; Panaitescu, C. A two-stage DEA model to evaluate agricultural efficiency in case of Serbian districts. Econom. Agric. 2019, 66, 965-974.

17. Yan, L.P. Evaluation of operating efficiency of agricultural listed enterprises based on DEA-tobit two stage model. In Proceedings of the International Conference on Modeling, Analysis, Simulation Technologies and Applications (MASTA 2019), Hangzhou, China, 26-27 May 2019; Atlantis Press: Paris, France, 2019; pp. 47-53.

18. Raheli, H.; Rezaei, R.M.; Jadidi, M.R.; Mobtaker, H.G. A two-stage DEA model to evaluate sustainability and energy efficiency of tomato production. Inf. Process. Agric. 2017, 4, 342-350. [CrossRef]

19. Vlontzos, G.; Niavis, S.; Pardalos, P. Testing for environmental Kuznets curve in the EU agricultural sector through an eco-(in) efficiency index. Energies 2017, 10, 1992. [CrossRef] 
20. You, H.; Zhang, X. Ecoefficiency of intensive agricultural production and its influencing factors in China: An application of DEA-Tobit analysis. Discret. Dyn. Nat. Soc. 2016, 2016. [CrossRef]

21. Ray, S.C.; Ghose, A. Production efficiency in Indian agriculture: An assessment of the post green revolution years. Omega 2014, 44, 58-69. [CrossRef]

22. Hansson, H.; Öhlmér, B. The effect of operational managerial practices on economic, technical and allocative efficiency at Swedish dairy farms. Livest. Sci. 2008, 118, 34-43. [CrossRef]

23. Javed, M.I.; Adil, S.A.; Ali, A.; Raza, M.A. Measurement of technical efficiency of rice-wheat system in Punjab, Pakistan using DEA technique. J. Agric. Res. 2010, 48, 227-238.

24. Frija, A.; Wossink, A.; Buysse, J.; Speelman, S.; Van Huylenbroeck, G. Irrigation pricing policies and its impact on agricultural inputs demand in Tunisia: A DEA-based methodology. J. Environ. Manag. 2011, 92, 2109-2118. [CrossRef]

25. Escobar, N.; Tizado, E.J.; zu Ermgassen, E.K.; Löfgren, P.; Börner, J.; Godar, J. Spatially-explicit footprints of agricultural commodities: Mapping carbon emissions embodied in Brazil's soy exports. Glob. Environ. Change 2020, 62, 102067. [CrossRef]

26. Ayaz, S.; Hussain, Z.; Sial, M.H. Role of credit on production efficiency of farming sector in Pakistan (A data envelopment analysis). World Acad. Sci. Eng. Technol. 2010, 60, 1028-1033.

27. Choi, Y.; Yang, F.; Lee, H. On the unbalanced atmospheric environmental performance of major cities in China. Sustainability 2020, 12, 5391. [CrossRef]

28. Mei, G.; Gan, J.; Zhang, N. Metafrontier environmental efficiency for China's regions: A slack-based efficiency measure. Sustainability 2015, 7, 4004-4021. [CrossRef]

29. Choirina, V.N.; Hartono, S.; Suryantini, A. Supply response analysis of paddy in Kediri: Managerial implications. Agro Ekon. 2016, 27, 107-120. [CrossRef]

30. Long, X.; Oh, K.; Cheng, G. Are stronger environmental regulations effective in practice? The case of China's accession to the WTO. J. Clean. Prod. 2013, 39, 161-167. [CrossRef]

31. Kutlar, A.; Kabasakal, A.; Sarikaya, M. Determination of the efficiency of the world railway companies by method of DEA and comparison of their efficiency by Tobit analysis. Qual. Quant. 2013, 47, 3575-3602. [CrossRef]

32. Sharma, K.R.; Leung, P.; Zaleski, H.M. Technical, allocative and economic efficiencies in swine production in Hawaii: A comparison of parametric and nonparametric approaches. Agric. Econom. 1999, 20. [CrossRef]

33. Galanopoulos, K.; Aggelopoulos, S.; Kamenidou, I.; Mattas, K. Assessing the effects of managerial and production practices on the efficiency of commercial pig farming. Agric. Syst. 2006, 88. [CrossRef]

34. Choi, Y.; Lee, H.; Debbarma, J. Are global companies better in environmental efficiency in India? Based on metafrontier malmquist CO2 performance. Sustainability 2020, 12, 8359. [CrossRef]

35. Why Do Indian Businesses Need to Take Air Pollution Seriously? Available online: https://wri-india.org/blog/why-do-indianbusinesses-need-take-air-pollution652seriously (accessed on 14 May 2021).

36. India Greenhouse Gas Program. Available online: https://www.wri.org/our-work/project/india-greenhouse-gas-program (accessed on 14 May 2021).

37. $\mathrm{Hu}, \mathrm{Y}$. Energy conservation assessment of fixed-asset investment projects: An attempt to improve energy efficiency in China. Energy Policy 2012, 43, 327-334. [CrossRef]

38. Aggarwal, N.; Narayanan, S. Impact of India's demonetization on domestic agricultural markets. SSRN 2017. [CrossRef]

39. Demonetisation Will Hit Agriculture, Informal Workers Worst: Study (But It's Good Idea). Available online: https: / /archive. indiaspend.com/cover-story / demonetisation-will-hit-agriculture-informal-workers-worst-study-but-its-good-idea-56666 (accessed on 14 May 2021).

40. Latest Releases. Available online: https://censusindia.gov.in/2011-Common/Latest_Releases.html (accessed on 14 May 2021).

41. Publications. Available online: https://m.rbi.org.in/Scripts/PublicationsView.aspx?id=19992 (accessed on 14 May 2021).

42. Statewise Rainfall Information. Available online: https://mausam.imd.gov.in/imd_latest/contents/index_rainfall_state_new. php (accessed on 14 May 2021).

43. Zhang, J.F.; Fang, H.; Wang, H.X.; Jia, M.S.; Wu, J.J.; Fang, S.R. Energy efficiency of airlines and its influencing factors: A comparison between China and the United States. Resour. Conserv. Recy. 2017, 125, 1-8. [CrossRef]

44. Dalei, N.N.; Joshi, J.M. Estimating technical efficiency of petroleum refineries using DEA and tobit model: An India perspective. Comput. Chem. Eng. 2020, 142, 107047. [CrossRef]

45. Tirado, R.; Gopikrishna, S.R.; Krishnan, R.; Smith, P. Greenhouse gas emissions and mitigation potential from fertilizer manufacture and application in India. Int. J. Agric. Sustain. 2010, 8, 176-185. [CrossRef]

46. Velmurugan, A.; Dadhwal, V.K.; Abrol, Y.P. Regional nitrogen cycle: An Indian perspective. Curr. Sci. 2008, 94, $1455-1468$.

47. Sah, D.; Devakumar, A.S. The carbon footprint of agricultural crop cultivation in India. Carbon Manag. 2018, 9, 213-225. [CrossRef] 